\title{
The Effects of Globalization and Deregulation on Nigerian Culture Industries
}

\author{
E.A. Eregare and A.O.Afolabi* \\ Department of Theatre and Media Arts, Ambrose Alli University, Ekpoma, Edo State, Nigeria \\ *Department of Psychology, Ambrose Alli University, Ekpoma Edo State, Nigeria
}

KEYWORDS Globalization. Culture. Industries. Deregulation

\begin{abstract}
Culture industries are affected by today's moving forces globalisation and its twin brother deregulation as these firms expand their scope of market and capital. This paper shows how this trend called globalization has galvanized the relaxation of government control (deregulation) in the domain, which had allowed private participation in the culture industries. The paper however, cautions that despite the growth envisaged, care should be taken not to throw away what is sacrosanct in our society. We should not also follow in the steps of the developed nations where the power of the media are vested in the hands of very few corporations.
\end{abstract}

\section{INTRODUCTION}

Today, after more than a century of electrical technology, we have extended our central nervous system itself in a global embrace, abolishing both space and time and as far as our planet is concerned... as electrically contracted the globe is no more than a global village (McLuhan 1964). That apt saying of McLuhan, the Canadian media critic and theorists seems to encapsulate all the rhetoric about globalization today.

As technology and communication improve, man's hands seem longer and his ears sharper than usual, that he can feel and hear what is happening in far away lands. As the world contracts, the people merge, throwing away certain blockages and barriers, thereby, forging a unity that had never been seen in history. To make this possible is man's search for trade and comfort. Obstacles to these desires are government's intervention and stringent laws; hence, deregulation the twin brother of globalization is necessary. If companies must grow and create jobs, and foreign investment must come in, there must be the removal of all protectionist laws, which benefit local firms. Government must free itself of the business of business and concern itself with organizing and controlling the private investors. That is the basic tenant of deregulation - freedom to buy and sell without hindrance.

Globalization also goes beyond the economic aspect. It is social and cultural. Globalization as Giddens (1990) notes is the intensification of worldwide social relations, which link distant localities in such a way that local happenings are swayed by events occurring many miles away and vice versa. The vehicles for these social and cultural relations are the culture industries. These industries are responsible for the manufacturing of meanings whether they are news, drama, music, and films

\section{CULTURE INDUSTRIES}

Culture industries are those firms that produce meaning and symbols. This term was coined by the neo-Marxist school of critical political economy theory of the media. To the Frankfurt school of theoristst culture firms are like any other company that manufacture culture for onward transmission to the people. Adorno and Horkheiner (1977), liken culture industries to other consumer product factories, which utilize the same processes and involving the same relations. Everything is done to please the consumer, "the consumer becomes the ideology of the pleasure industry" (p. 377). Peter Golding and Graham Murdock (1996: 11) concur: "everyone from politicians to academics now agree that public communications system are part of the culture industries". They are industries because they manufacture goods like any other industry - newspapers, advertisements, television programs and feature films. They play a pivotal role in organizing the images and discourses through which people make sense of the world (1996: 11). The UNESCO commission says that the communication industry also include what hast come to be called the 'cultural industry' meaning that it produces, transmits cultural products or cultured and artistic works by industrial techniques 1980: 78). 
They went on to say that these cultural products include, books, films or recordings, television programs that are mass-produced for the mass audience. Kelner (1989), views the communication media as industries, which commercialize and standardize their products of culture. Serveas and Lie (2000) agree saying that media producers are businessmen that produce, distribute and sell marketable products: "the media being a cultural product itself". They continued, saying that the media as cultural products reflect the values of their producers and the social realities in which they are produced. In this era of globalization and deregulation, the question now is whose reality? It is none but that of the private business moguls who are bent on making profit by commercializing information and culture for their selfish gains.

With media and culture industries seen as that which produces goods meant for the consumer, one can see how the globalization bug could easily catch up with it. As these companies produce their products they influence the masses and cause them to act in a certain direction. Culture industries produce and expand the ideology or worldview of the people and present the way a people could be seen. Globalization and deregulation affects them as industries organized by the forces of production and the relations of production and the manner in which they are socially organized, Hall (1977). Relations of capital versus labor influence the ideology that is produced as the culture product. The media produces meaning or as Chaney (1977) calls it, "meaningful reality", reality being "a coherent view of experience which is held by individuals or groups" (Kreling 1976). Today, global culture as created by the culture industries posits divergent cum homogeneous representation, which is all the more confusing.

\section{Globalization}

The concept of globalization is not a new one, as the spirit to move beyond one's natural frontiers has been the preserve of man. In the quest for trade and resources man had always moved to other lands to visit or to conquer it. By so doing he is influencing and being influenced by the new peoples and culture. Held et al. (1999) agrees that globalization is not novel nor a modern social phenomenon, through its forms may have changed over time and across key scope of human endeavors.
There are several factors that are responsible for the growth of modern globalization. It could mostly be traced to the political changes in Europe; the fall of the Berlin wall in the 1990's and the growth of the World Wide Web (Servaes and Lie 2000). The opening up and eventual collapse of the USSR and the eastern bloc countries, which had since given way to international markets moneys and media (Srebeny-Mohammed 1996). A strong factor is the need for expansion of market for excess products. This led to economic interdependence, for globalization engenders a system whereby one country's economy will have an effect on that of other nations. This is done in a very large scale that a country's policies are formulated in such a way that it will be favorable to the international community.

Globalization is the process "whereby political social, economic and cultural relations increasingly take on a global scale which has propounded consequence for individual local experience and everyday lives" (Bilton 1997). It is a process through which the entire human population is bonded in a single society (Albrow 1990) or as Robertson (1990) defines it "a structuration of the world as a whole". O'Sullivan et al. (1994), see globalization as the growth of economic and cultural networks which operate on worldwide basis. The reasons for this growth is the "emergence of communications technology and media networks which allow faster, more extensive independents forms of world wide exchange, travel and interaction

Globalization could be said to be a process that has been and is still going on until the creation of a homogeneous community. There is the mixture of culture, which is made possible by the growth of information communication technology (ICT), and the advancement of media industries. The happenings in Africa can be influenced by events in the USA. The bombing of World Trade Center in the US sent tremors to the remotest parts of the world. Gurevitch (1996) explains that the great media events of our time such as the live broadcast of the landing on the moon or explosion of the Challenger shuttle or of sports such as the Olympic games, illustrate the marvel of the new technologies. Hollywood films and music could be seen and heard in almost every part of the world. Coca-Cola and the consumerist ideology it represents are felt all over the world. This is the spirit of globalization. 


\section{Trends in Globalization}

There are various arguments as to what form does globalization takes. Is it economic or cultural based? Adamu (2003) gives some approaches, saying that it is economic, cultural and political. Bairoch (2001: 197) supports the economic standpoint when he talks of a situation wherein industries and commercial companies as well as financial institution increasingly operate transnationally. This gives room for analyses of global economy as it affects all nations. This economic feature of globalization gives birth to privatization and deregulation for, globalization strives because micro-economic forces initiated by multinational and trans-national companies (T.N.C).

Globalization could be cultural. It is this force that blends the people together into one global community. People are distinct because of their culture, but as information communication technology (ICT) and media technology break ethnic barriers and erode national identities a homogeneous entity is created. Political discourses on globalization see it as a powerful tool that makes the nation state powerless. Global issues seem to undermine the sovereignty of individual nations. Government policy formulation and implementation are done to favor industrialized countries and investing transnational companies (T.N.C). Real powers have been ceded to Para-governmental organization like the World Bank, I.M.F. and other organs of the United Nations, (Adamu 2003).

Many hold the view that globalization is so powerful in its influence on both the individual and society. While some argue to the contrary. Held et al. (1999, 2000) gives three categories in explaining how people see globalization and its influence. They are the Globalists, the Traditionalists and the Transformationalists. The Globalists are those who see globalization as a powerful force that cannot be resisted or be significantly influenced by human intervention through traditional political intervention such as nation states. The Traditionalists argue that the whole talk about the power of globalization is a ruse, that most economic and social activity is regional, that there is still power and importance in the nation states. They believe that globalization is a myth. The Transformationalists are in the middle, though they agree that globalization has some impact on the scheme of things but question the degree of this influence. They maintain that there is still significant scope for national and local agencies. These pessimistic and optimistic views about the influence and power of globalization are best situated in the reasons they proffer.

\section{Hopes and Fears of Globalization}

To some people globalization is the answer to all things while others believe it's a monster that should be handled with caution. These are some of the hopes of the optimists.

1. Rise in the Volume of Global Market: No matter the product, whether films, news, records or advertising there will be an increase since international trade will boom as there will be no obstacles in entering any market. The proliferation of American symbols is an example of this penetration markets.

2. Increase in Competition: There will more choices, which will lower prices, and more profits through increase in the volume of trade. As many players enter the industry professionalism will be engendered.

3. Cultural Diversity: Cultural diversity will be present, as there will be a plethora of cultural products available to the individual.

4. Job creation and Poverty Eradication: As more activities take place in the media and culture sector more jobs will be created.

5. Check on Bad Government: Global media and media globalization will help check tyrannical government and undemocratic government policies. Foreign media can make criticism of government and local audience can get access to them. Global media could also be used as a public relation tool by government as they can act a "go between", a channel of communication between countries and leaders. If constructs world public opinion and followership.

6. Aid Development: Instant access to media coverage of local activities could open up the nation to development. Global culture industries will alter the altitude and values of underdevelopment in the people.

Contrarily, the pessimists have some fears believing that globalization and its global culture portends no good for the developing nation

1. Culture and Media Imperialism: With media flow almost one way from the developed nations to the third world, there will only be the imposition of foreign values. This undermines the development enumerated above. According to Boyd-Barrett (1977), the influence of America 
media content and advertising only intensifies consumption values instead of production values that are needed for economic growth. Globalization, many agree, is another form of recolonization. According to Abdul-Raheem (2003) it is the "'truimphalism" about the hegemony of western value, ideas and civilization". Globalization is a euphemism for Americanization as all people of the world think and dream Hollywood and America.

2. Cultural Homogeneity: As opposed to the theory of cultural diversity, globalization only breeds a further melting down of cultures, where the less powerful ones are submerged into that of the powerful American and European cultures. With the proliferation through mass production of foreign culture there is a gently eroding of local culture. There is the destruction of the local for the global.

3. Loss of Jobs: The local companies who cannot complete with large T.N.C will be forced to close shop and so many able-bodied professionals will be laid off jobs

These fears and hopes though tenable, one would prefer to take the middle course because as the forces of globalization move on, the local also is made to assert itself. It has been proven that local TV programs and records get more ratings and audience than imported foreign ones (Srebenny-Muhammed 1996; Ferguson 1995; Servaes and Lie 2000). The snag here is that, as the impact of culture through popular culture is gradual and sustained it will take only time before the fears of the pessimists will come to fruition.

\section{Deregulation as Agent of Globalization}

One important aspect in this age of globalization is the policy of deregulation. Deregulation as a notion is borrowed from the capitalist West. It is a system in which government slackens the laws of control in business or even outright withdrawal from it. It is characterized by privatization, and government selling off her shares in major companies and government bodies are then set to regulate, supervise and control private participation.

Deregulation is a notion of the world trade council (W.T.O), formally (UNCTAD). Member nations are to allow free trade amongst themselves and create enabling environment for foreign companies to enter local markets. Nigeria is a founding member. However, the Oneworld website (2003) say that the "free trade benefits" is merely an avenue for transnational corporations to sweep aside smaller competitions no matter the social or environmental cost. Deregulation which is supposed to bring about healthy competition, Ferguson (1995), notes is a misnomer: "sustainable competition is an oxymoron of the first order when market liberation calls for competition, but function by its elimination through mergers, alliances and acquisitions". Deregulation is supposed to engender freedom of trade and a check against monopoly that limits trade but what is done in reality is to allow these T.N.C.s grow so large through mergers, alliances that they swallow up competitions. The result is that they end up controlling the market. For the culture industries their views and ideologies are sold to the world. It is no exaggeration to say that the producers of $60 \%$ of the worlds cultural products are not more than 10 U.S. and Japanese companies who have interest in the media of TV radio, newspapers, films records and so on.

Deregulation has been a concept in the media scope of the United States of America and Europe for a long time. As far back as 1934 the Federal Communication Commission (F.C.C) was established in the U.S. to regulate broadcasting and telecommunications since then, it has been in fore front in the fight against monopoly in the electronic media. Its main concern is that media power does not remain in the hands of a very few. These rules were slackened through the years that today very few firms control culture from production, distribution to marketing.

In Nigeria, deregulation in the broadcast media of television and radio could be said to begin in 1992 when the Nigerian Broadcasting commission was set up. This brought to an end to government (state and federal) monopoly. Since then the NBC had given license to more than 15 private TV and radio companies.

The print media one could say is properly deregulated with the Nigerian press council performing some controlling roles. There is freedom of entry for any firm willing to participate in the industry.

The film industry was almost comatose because government of neglect, but through the efforts of private producers, who stumbled on home video films, it has been revived. It is a completely, deregulated sector. Record companies, which were in the country left because of the economy and acts of pirates, and deregu- 
lation has not been able to bring them back In Nigeria, deregulation has not brought the muchexpected growth but progress is being made.

\section{Effects of Globalization and Deregulation on Nigerian Culture Industries}

What is the impact of Globalization and deregulation on Nigeria culture industries of films, records, TV and radio? These media are so powerful that they can influence and change the attitudes and values of those who are exposed to it (Eregare 2002). It is predicated on this view that one critically evaluates globalized media with its attendant themes; representations and ideas, for this could have some effects in the local culture. American ideas and way of life could be seen in every aspect of our life. That is the power of culture industry.

Effects of globalization and deregulation could be seen in the following segments of the sector. Production, content and reception Gurevitch (1996) rightly posits that globalization process and is a mixture of technology, issues of information flow, and question of audience comprehension and reception. Let us take a look at production, content and audience reception of culture industries in Nigeria.

Production of Media: In looking at production we shall concern ourselves with ownership, control, technology and production techniques. Who own the media determine who controls it. In Nigeria, ownership of the broadcast media is vested on the public (states and federal governments) and private citizens. It is the Nigerian Broadcasting Commission (NBC) who regulates the media. Its main aims are to safeguard national security and uphold cultural values of Nigeria. We can see that the government (Federal and state) is the largest owners of broadcast media in the country. The Federal government has the largest Television station - the Nigeria Television Authority (NTA), which has more than 40 stations in its network. She also has the Federal Radio Corporation of Nigeria (F.R.C.N.) owners of ' the federation. The federal government also has the Voice of Nigeria (V.O.N), though it is external broadcast organ. Almost all state governments have a radio and or TV station.

With deregulation, private TV and Radio station sprung up but yet government still has the monopoly of having the only TV and radio network in the country. The efforts of DAAR communications owners of A.I.T and Ray Power to compete is still being thwarted by N. B. C. and some state governments. The print media is much deregulated, as private ownership is rife, though government has some presses. Because of this the influence of print journalism in the polity is strong. The Film today is a purely private affair as government through the Nigerian Film Corporation (NFC), is almost redundant. Though the celluloid film has not been produced for a long time the Home Video film had replaced it with Igbo and Yoruba films having a field day. Records companies one purely produced by private concerns and all of them locally owned.

The technology of production is an important aspect. Nigeria is a third world country so it may not be able to afford digital technology that is used in the media today. However, The NBC had instructed that all Radio and TV station to go digital by the end of the year.

Content of Media: The representations of media and issues in News and other programs are greatly influenced by the global spirit. Nigeria films, T V and Records portray the dominant America culture and this could be traced to factors like lack of funds to produce programs, proliferation of Hollywood culture, and dependency on foreign News Agencies of developed countries.

The contents of these products show the influence of Americanization. TV and radio are filled with syndicated foreign programs. Though Home Videos portray Nigeria themes and characters. They are rendered in the Hollywood style of fashion, sex and violence and these derail African values (Eregare 2002).

Reception of media: Nigeria today has over 100 T.V stations and over 90 radio stations, 19 satellite and cable stations. The Record/Music companies are purely disorganized but KENIS music Premier sounds are trying to bring some order by supporting up and coming musicians. The film industry has a proliferation of producers and workers whom in dire need of organization. How do the audience set to see what is produced. Several data has proved that third world Africa has a low access to media products, with less than $40 \%$ of the population having TV set and ten than $60 \%$ with owing radio sets.

Today, cinema going is almost none-existent. The home video rentals are the means where films get to the people. Records companies are almost run aground by pirates who make available 
records to the population in almost every corner of the country. In the print media, reception is somewhat limited to the literate in the society, even some percentage of the literate people are too poor to afford the newspapers and magazines. Understanding the symbols used is also a case when judging audience reception of media. Though most media is done in English and local languages, the global and world cultural style of presentation obscure comprehension.

\section{Implication of Globalization}

Though deregulation has not brought in foreign media companies in the country, we are here saying that they are coming. The trend is for them to merge, acquire themselves and take over them world. Hollywood is producing films, which do not have too much cultural leanings so that they can be considered for a universal market (Boyd-Barret 1977). Mergers are taking place all over the world. These are some negative indications of too much concentration of media in few firms: Corporate influence on domestic and foreign policy. Corporate influence on whom gets elected into public office. Corporate choice of coverage and portrayal of information and people, A communication system where people cannot speak for themselves, encouraging exclusion of information and perspectives that don't fit with the interest of corporate media owner. With greater concentration of mass media on fewer hands, local news and information is sacrificed. These giants like the Time-Warner group, owners of CNN with their mergers with Turner Broadcasting, Microsoft merged with NBC, Murdock"s media conglomerates, CBS and Westinghouse and M.C.A and Seagram owned the media and culture space of the world. Therefore, as Nigeria's economy improves and with deregulation put in place they will come in and set up house or buy over the successful media houses like DAAR, and Minaj. That is the trend.

\section{CONCLUSION}

We have said that globalization is a means whereby the political boundaries of nation are no longer important in matters of trade and culture flow. The implication for this is that attitudes and values are constantly being changed, soon there will be a homogenous culture with the powerful consumerists American culture winning the day. There should be the need to prevent the over influence of the global over the local, with its attendant loss of identify. There will not be much to gain from this trend if it destroys the base of our worldview. Efforts must be put in place to improve the local in the global sphere, these things are recommended.

Barriers to W.T.O agreement on media flow not withstanding, the government should take steps to block overt inflow of cultural media like Europe is doing against American films and other culture products. This will cause increase in production by culture industry and checks induced proliferation of negative cultural products.

Government should create enabling environment for mergers of smaller media and culture firms so that they can compete with their foreign counterparts.

The NBC and other regulatory bodies should be up and doing in checking foreign influence on the local media. This is not to be used as a means to clamp down of critical voice of against government. Regulation is necessary to retain a communication system in which equitable access, equal opportunity and diversity of opinions can thrive. This is because ownership and control influence what eventually is produced and this ultimately affects the audience the present of commodification and consumerist ideology should not be allowed to strive and debase our standards and values. Globalization though will increase trade and commerce might put the nation in further jeopardy.

\section{REFERENCES}

Abdul-Raheem T 2000. Globalisation and recolonization. www.indianseminar.com $/ 200490 \%$ abdulraheem

Adamu FL 2003. Globalization and Economic Globalization in Northern Nigeria. www. devstand.org .UK/ Publication.

Adorno T, Horkheimer M 1977. The Culture Industry Enlightenment as Mass Deception; (abridged). In: J Curran, M Gurevitch, J Woolacott (Eds.): Mass Communication and Society. London: Edward Arnold, pp. 349-383.

Albrow M 1990. Globalization knowledge and Society. In: M Abrow, King (Eds.): Knowledge and Society. London: Sage Publications, pp. 73-107.

Bairock P 2000. The Constitute Economic Principles of Globalization in Historical Perspectives: Myths and Realities. International Sociology Journal of International Sociological Association, 15(2): 197214 
Bilton T 1997. Introductory Sociology. UK: MacMillan. Boyd-Barret O 1977. Media Imperialism: Toward an International Framework for Analysis of Media Systems. In: J Curran, M Gurevitch, J Woollacott (Eds.): Mass Communication and Society. London: Arnold, pp.116-135

Channey D 1977. Fictions in Mass Entertainment. In: J Curran, M Gurevitch, J Woollacott (Eds.): Mass Communication and Society. London: Edward Arnold, pp. 440-457.

Eregare EA 2002. Values, Standards and Censorship: A Study of Nigeria Film and Video Censors Board $(N F V C B)$. An unpublished M.A.Thesis, submitted to the University of Ibadan.

Featherstone M 1995. Global Culture: An Introduction. In: M Featherstone (Ed.): Global Culture. London: Sage Publications, pp. 1-17.

Ferguson M 1992. The Mythology about Globalization. European Journal of Communication, 7: 69-93.

Ferguson M 1995. Media Markets and Identities: Reflections on the Global-Local Dialectic. Canadian Journal of Communication, 20(4): 11- 33, Open Journal System, www.cjc.online.ca/viewarticle. php?id.=313\& layout.html.

Giddens A 1990. The Consequence of Modernity. Stanford CA: Stanford University Press.

Giddens A 1995. Modernity and Self-Identity: Self and Society in the Late Modern Age. UK: Cambridge Press.

Golding P, Murdock G 1996. Culture Communication and Political Economy. In: J Curran, M Gurevitch (Eds.): Mass Media and Society. London: Arnold, pp. 2-34.

Gurevitch M 1996. Globalization of Electronic Journalism. In: J Curran, M Gurevitch (Eds.) Mass
Media and Society. $2^{\text {nd }}$ Edition, London: Arnold, pp. 205-224.

Hall S 1977. Culture, the Media and the Ideological Effect. In: J Curran, M Gurevitch, J Woollacott (Eds.): Mass Communication and Society. London: Arnold, pp. 315-348.

Held D, A McGrew, D Goldbert, J Perraton 1999. Global Transformations. Politics, Economics and Culture. Cambridge: Polity Press.

Held D 2002. Regulating globalization? The reinvention of Politics. International Sociology Journal of International Sociological Association, 15(12): 394408 .

Kellner D 1989. Critical Theory, Marxism and Modernity. Cambridge: Polity Press

McLuhan M 1964. Understanding Media. London: Routledge, Kegan Paul

One world Available www.Islandnet.com/ ncfs/maisite/ global.htm>.

O'sullivan T, Brains D, Phillip R 1996. Studying the Media: An Introduction. London: Arnold.

Robertson R 1992. Globalization: Social Theory and Global Culture. London: Sage.

Servaes J, Rico L 2000. Media versus globalization and localization and or through? Internet freenet002 @ pi.be of Rico. Lie.

Sreberny-Mohammad A 1996. The Global and the Local in International Communications. In: J Curran, M Gurevitch (Eds.): Mass Media and Society. $2^{\text {nd }}$ Edition, London: Arnold, pp. 177-203.

UNESCO 1980. Many Voices One World: Communications Today and Tomorrow. UNESCO Report. Ibadan: U.I. Press.

Wallerstein I 1990. Culture as the ideological battle ground of the Modern World System. In: M Featherstone (Ed.): Global Culture. London: Sage, pp. 37-59. 